Research Article

http://dx.doi.org/10.17784/mtprehabjournal.2014.12.180

\title{
Determinant factors for mortality of patients receiving mechanical ventilation and effects of a protocol muscle training in weaning.
}

\author{
Fatores determinantes da mortalidade em ventilação mecânica e os efeitos de dois protocolos \\ de desmame respiratório.
}

\begin{abstract}
Juliana Mitiko Shimizu(1), Roberta Munhoz Manzano(2), Robison José Quitério(2), Valdirene Tenório da Costa Alegria(3), Telma Tortorelli Junqueira(3), Silene El-Fakhouri(4), Alexandre Ricardo Pepe Ambrozin(2).

Departamento de Fisioterapia e Terapia Ocupacional (DEFITO) da Universidade Estadual Paulista: "Júlio de Mesquita Filho" (UNESP), Campus Marília, Marília (SP), Brasil.
\end{abstract}

\begin{abstract}
Introduction: Prognostic factors are used in the Intensive Care Unit (ICU) to predict morbidity and mortality, especially in patients on mechanical ventilation (MV). Training protocols are used in MV patients with the aim of promoting the success of the weaning process. Objective: To assess which variables determine the outcome of patients undergoing mechanical ventilation and compare the effects of two protocols for weaning. Method: Patients under MV for more than 48 hours had collected the following information: gender, age, ideal weight, height, Acute Physiology and Chronic Health Evaluation (APACHE II), risk of mortality, Glasgow Coma Scale (GCS) and index Quick and perfunctory (IRRS) breathing. Patients with unsuccessful weaning performed one of weaning protocols: Progressive $T$ - tube or tube - T + Threshold ${ }^{\circledR}$ IMT. Patients were compared for outcome (death or non-death in the ICU) and the protocols through the test or Mann-Whitney test was considered significant when $P<0.05$. Results: Of 128 patients evaluated $56.25 \%$ were men, the mean age was $60.05 \pm 17.85$ years and $40.62 \%$ patients died, and they had higher APACHE II scores, mortality risk, time VM and IRRS GCS and the lower value $(p<0.05)$. The age, initial and final maximal inspiratory pressure, time of weaning and duration of MV was similar between protocols. Conclusion: The study suggests that the GCS, APACHE II risk of mortality, length of MV and IRRS variables determined the evolution of MV patients in this sample. Not found differences in the variables studied when comparing the two methods of weaning.
\end{abstract}

Keywords: Intensive Care Unit; Mortality; Ventilator weaning; Respiration, artificial; APACHE; Airway extubation.

\section{Resumo}

Introdução: Fatores prognósticos são usados na Unidade de Terapia Intensiva (UTI) para predizer morbimortalidade, especialmente em pacientes em Ventilação Mecânica (VM). Protocolos de treinamento são utilizados em pacientes em VM com o intuito de promover o sucesso no processo de desmame ventilatório. Objetivo: Avaliar quais variáveis determinam a evolução de pacientes submetidos à ventilação mecânica e comparar os efeitos de dois protocolos de desmame ventilatório. Método: Pacientes em VM por mais de 48h tiveram as seguintes informações coletadas: sexo, idade, massa ideal, estatura, Acute Physiology and Chronic Health Evaluation (APACHE II), risco de mortalidade, Escala de Coma de Glasgow (ECGI) e Índice de Respiração Rápida e Superficial (IRRS). Pacientes com insucesso de desmame realizaram um dos protocolos de desmame: Tubo-T progressivo ou Tubo-T + Threshold ${ }^{\circledR}$ IMT. Os pacientes foram comparados quanto ao desfecho (óbito ou não-óbito na UTI) e quanto aos protocolos por meio do Teste t ou Teste Mann-Whitney, foi considerado como significante p<0.05. Resultados: Dos 128 pacientes avaliados 56,25\% eram homens, a idade média era 60,05 $\pm 17,85$ anos e 40,62\% pacientes foram a óbito, sendo que estes apresentaram maiores valores de APACHE II, risco de mortalidade, tempo de VM e IRRS e menor valor de ECGI $(p<0,05)$. A idade, pressão inspiratória máxima inicial e final, tempo de desmame e tempo de VM entre os protocolos foi semelhante. Conclusão: O trabalho sugere que as variáveis ECGI, APACHE II, risco de mortalidade, tempo de VM e IRRS determinaram a evolução de pacientes em VM nesta amostra. Não foi encontrado diferença nas variáveis estudadas quando comparados os dois métodos de desmame ventilatório.

Palavras-chave: Unidade de Terapia Intensiva; Mortalidade; Desmame do Respirador; Respiração, artificial; APACHE; Extubação.

Received: 28 February 2014. Accepted: 27 May 2014. Published: 2 June 2014.

1. Physiotherapist from Universidade Estadual Paulista Júlio de Mesquita Filho (UNESP), Marília (SP) Brazil.

2. Professor of Physical Therapy School at Universidade Estadual Paulista Júlio de Mesquita Filho (UNESP), Marília (SP), Brazil.

3. Physiotherapist of Intensive Care Unit at Hospital das Clínicas da Faculdade de Medicina de Marília (FAMEMA), Marília (SP), Brazil.

4. Intensive Doctor of Intensive Care Unit at Hospital das Clínicas da Faculdade de Medicina de Marília (FAMEMA), Marília (SP), Brazil.

Corresponding Author:

Roberta Munhoz Manzano - DEFITO - Departamento de Fisioterapia e Terapia Ocupacional - Avenida Hygino Muzzi Filho, 737. Bairro Campus Universitário. Zip Code: 17525-900. Marília-SP. Phone: (14) 34021350 


\section{INTRODUCTION}

Intensive Care Unit (ICU) patients that requires ventilatory support will increase costs and hospital stay. (1) Methods to assess the severity and prognosis of patients are extremely important, since it allows the real benefit of new therapeutic interventions and detect possible treatment failures. ${ }^{(1-5)}$

Another relevant aspect of the patient in the ICU is the need for mechanical ventilation (MV) for a long period, which means more than $40 \%$ of total time is spent in the MV wean procedures. ${ }^{6,7)}$ Techniques that accelerate the weaning through protocols decrease the time $\mathrm{MV}{ }^{(6,8)}$ enabling greater success in weaning and lower incidence of complications associated with VM. $(9,10)$

Among weaning protocols, Spontaneous Breathing Trial (SBT) made by the T-tube is the most used because it is simple, easy to perform, short application and deliver results extubation. ${ }^{(8,11-13)}$ The rapid shallow breathing index (RSBI) ${ }^{(7)}$ with less than $105 \mathrm{bpm} / \mathrm{L}$ values are able to identify patients who will be successfully extubated. $(7,14,15)$

Despite the use of terms and indices that offer security decision for extubation, other factors may influence weaning, among them respiratory muscle weakness. (11,16-18) In addition to the deleterious effects of MV critically ill patients has increased cytokines inflammatory and nutritional deficits, factors associated with bed rest and exposure to pharmacologic agents potentiate muscle dysfunctions. ${ }^{(16)}$

Thus, evidence suggests that the respiratory muscle training (RMT) with load increase can increase muscle strength and reduce dyspnea ${ }^{(19,20)}$ improve vital capacity and decrease the length of hospitalization. ${ }^{(21)}$

The influence of the RMT at the time of weaning the patient in prolonged MV is still controversial, since some authors observed shorter weaning in patients who underwent training ${ }^{(22,23,24)}$ while others do not. ${ }^{(25,26)}$ Few studies research regarding the use of RMT devices in optimizing weaning exists there are no clear recommendations for their use. (7) We believe that the RMT can be beneficial for patients on MV for short periods that respiratory muscle weakness and consequently may experience difficulty in weaning.

Considering the above, the primary objective of the study was to evaluate which variables determine the outcome of patients undergoing mechanical ventilation and as a secondary objective was to compare the effects of two methods of weaning in mechanically ventilated patients.

\section{METHOD}

It was performed a prospective observational cohort study with a randomized interventional part. The study was realized at ICU of the Hospital das Clínicas da Faculdade de Medicina de Marília after approval of the institution's Research Ethics Committee (protocol $n^{\circ}$ 1432/11). The guardians of the patients were informed about the objectives, benefits and risks of the study and those who agreed signed an informed consent (IC).

A hundred and twenty-eight patients, older than 18 years old, admitted from May to October 2012, undergoing MV for more than 48 hours regardless of the underlying disease were studied. Patients with neuromuscular diseases and spinal cord injury, responsible refused to sign the consent form or who were extubated before completing 48 hours of MV were excluded.

Of the patients included in the study the following data were recorded on admission: gender, age, ideal weight, height, scale of Acute Physiology and Chronic Health Evaluation (APACHE II)(5), mortality risk(5), Glasgow Coma Scale(27), etiology of respiratory failure, peripheral oxygen saturation and vital signs.

The height was calculated using the wingspan divided by 1.06 for males and 1.03 for female. ${ }^{(28)}$ To calculate the ideal weight considered the ideal body mass index (BMI) of $22.5 \mathrm{~kg} / \mathrm{m}^{2}$ and used the BMI = weight / height ${ }^{2}$ formula.

Patients were also classified according to the etiology of respiratory failure and may be surgical (general postoperative), neurological (cranial trauma, stroke, chronic subdural hematoma), lung (bronchospasm, pneumothorax, pulmonary congestion, pneumonia, chronic pulmonary obstructive disease, pleural effusion), trauma (multiple trauma, fractures), cardiac (acute pulmonary edema, congestive heart failure, cardiogenic shock) or other causes.

Patients were eligible to start weaning when they were with the underlying disease treated hemodynamically stable (good tissue perfusion, independence or low/stable doses of vasopressor, absence of decompensated coronary insufficiency or arrhythmias with hemodynamic consequences), adequate oxygenation (arterial oxygen pressure greater than or equal to $60 \mathrm{mmHg}$ with inspired oxygen fraction (FiO2) less than or equal to $40 \%$ ), positive end expiratory pressure (PEEP) less than $8 \mathrm{cmH} 2 \mathrm{O}$ and presence of inspiratory effort.(7)

In patients who met the criteria mentioned above ventilatory weaning was performed by means of the spontaneous breathing trial (SBT), which the endotracheal tube was disconnected from the mechanical part and connected to a ventilator in a " $\mathrm{T}$ " ( $\mathrm{T}$-tube) without directional valve, with continuous nebulization of oxygen (5l/min) to breathe spontaneously.

Before the SBT were performed manometer for measurement of maximal inspiratory pressure (MIP) and respirometry, spontaneously, to obtain the Tidal Volume (TV) in liters and calculate the rapid shallow breathing index (RSBI). ${ }^{(14)}$ The MIP was evaluated using manometer portable aneroid (Commercial Medica $($ ) ) with the patient in Fowler 45, coupled to a unidirectional valve 
via T-piece and occluded valve for 20 seconds position. (29) To obtain the TV, the spirometer (Wright ${ }^{\circledR} M k$ 8) was connected to the endotracheal tube for one minute and counted the respiratory rate (RR). The TV was calculated by dividing the volume obtained in a minute by $R R$ and the RSBI dividing the RR by TV. ${ }^{(14)}$

During the SBT were verified the vital signs, peripheral oxygen saturation and Glasgow Coma Scale.

The literature suggests that whereas from 30 to 120 minutes of SBT. In this study, patients that supported the test for 90 minutes, which means, maintained a $\mathrm{RR}$ less than $35 \mathrm{bpm}$, peripheral oxygen saturation greater than $90 \%$, HR less than 140 bpm, systolic blood pressure than 180 and greater than and $90 \mathrm{mmHg}$, Glasgow Coma Scale greater than eight and no signs of agitation and sweating would be considered successful SBT and extubated. Those who did not reach these criteria or not remained extubated after spontaneous breathing for more than 48 hours were considered weaning failure. ${ }^{(7)}$

Patients who failed the SBT performed one of weaning protocols. The choice of protocol was made by drawing, with sealed envelopes containing the name of each protocol (Progressive T-tube or T-tube + Threshold (R) IMT).

\section{Protocols}

In progressive T-tube protocol the patient was placed on spontaneous breathing in T-tube, each hour (Table 1 ), totaling eight times per day. The training time began with five minutes and if the patient did not have signs intolerance grew up in $100 \%$, every day and so on, resulting in four steps (Table 2 ), ie four days of training. Between moments of training the patient returned to MV in ventilation mode set by the service staff.

In T-tube + Threshold ${ }^{B}$ IMT protocol the patient was in T-tube training associated with respiratory muscle strength training with Threshold ${ }^{\circledR}$ IMT equipment according to schedules, milestones, and charges described in Tables 1 and 2. Training with Threshold $®$ IMT was performed twice a day, with the patient in Fowler $45^{\circ}$ position and charge of $50 \%$ of the MIP obtained by pressure manometry performed daily during the first hours of the protocol. Three sets of 10 breaths and rest on a mechanical ventilator for one minute between sets were performed, the ventilation mode set by the service staff.

Signs of intolerance during the protocols patients with RR greater than $35 \mathrm{bpm}$, peripheral oxygen saturation less than $90 \%$, HR greater than $140 \mathrm{bpm}$, systolic blood pressure greater than 180 or less than $90 \mathrm{mmHg}$, signs of agitation, sweating and Glasgow Coma Scale less than eight ${ }^{(7)}$ were considered and if the patient presented these signs the protocol was interrupted and resumed after 24 hours, no increase in the time of T-tube.
For 24 hours the patients were then returned to MV and medical criteria could be sedated.

If the patient has passed the stage of the protocol without signs of intolerance and bear the SBT conducted in the next day, he could was extubated. Those patients that completed all phases of the protocol and did not meet the criteria for extubation in the SBT were considered unsuccessful weaning.

For all MV patients were considered outcomes (death/no death) and total duration of MV (the first day of intubation until extubation or death). For those patients who underwent weaning protocols was also calculated time of weaning, counted from the first day until the last step protocol. The study design is found in Figure 1 .

\section{Statistical Analysis}

Data are presented as mean and standard deviation and passed normality D'Agostino and Shapiro Wilk test. The t test was used for normally distributed data and the Mann-Whitney test for data with non-normal distribution, to compare the variables age, height, ideal weight, APACHE II, risk of mortality, Glasgow, MV time and RSBI between patients who died or not. Patients who underwent protocols (Progressive T-tube or T-tube + Threshold $($ IMT) were also compared in terms of age, initial and final MIP (MIP's first and last day of the protocol, respectively), time of weaning and MV time. The level of significance was set at $5 \%$, and two-tailed.

\section{RESULTS}

A hundred and twenty-eight patients were evaluated, 72 men (56.25\%) and 56 women (43.75\%) with

Table 1. Protocols for weaning ( $1^{\text {a }}$ step)

\begin{tabular}{|c|c|c|}
\hline Hours & Progressive T-tube & T-tube + Threshold $®$ IMT \\
\hline $8 \mathrm{~h}$ & 5 minutes of T-tube & 5 minutes of T-tube \\
\hline $9 \mathrm{~h}$ & 5 minutes of T-tube & 5 minutes of T-tube \\
\hline $10 \mathrm{~h}$ & 5 minutes of T-tube & Threshold $®$ IMT \\
\hline $11 \mathrm{~h}$ & 5 minutes of T-tube & 5 minutes of T-tube \\
\hline $14 \mathrm{~h}$ & 5 minutes of T-tube & 5 minutes of T-tube \\
\hline $15 \mathrm{~h}$ & 5 minutes of T-tube & Threshold@ IMT \\
\hline $16 \mathrm{~h}$ & 5 minutes of T-tube & 5 minutes of T-tube \\
\hline $17 \mathrm{~h}$ & 5 minutes of T-tube & 5 minutes of T-tube \\
\hline
\end{tabular}

Table 2. Protocols for weaning steps

\begin{tabular}{lll}
\hline Steps & Progressive T-tube & $\begin{array}{l}\text { Threshold® IMT } \\
\text { (Work }-\% \text { da MIP) }\end{array}$ \\
\hline 1 & 5 minutes of T-tube & $3 \times 10$ repetitions $(50 \%)$ \\
2 & 10 minutes of T-tube & $3 \times 10$ repetitions $(50 \%)$ \\
3 & 20 minutes of T-tube & $3 \times 10$ repetitions $(50 \%)$ \\
4 & 40 minutes of T-tube & $3 \times 10$ repetitions $(50 \%)$ \\
\hline
\end{tabular}


mean age of $60.05 \pm 17.85$ years, who had respiratory failure due to changes: $32.81 \%$ of surgical causes $(n=$ $42), 27.34 \%$ neurological $(n=35) 16.41 \%$ lung $(n=$ $21), 6.25 \%$ traumatic $(n=8) 4.69 \%$ heart $(n=6)$ and $12.5 \%$ other causes $(n=16)$.

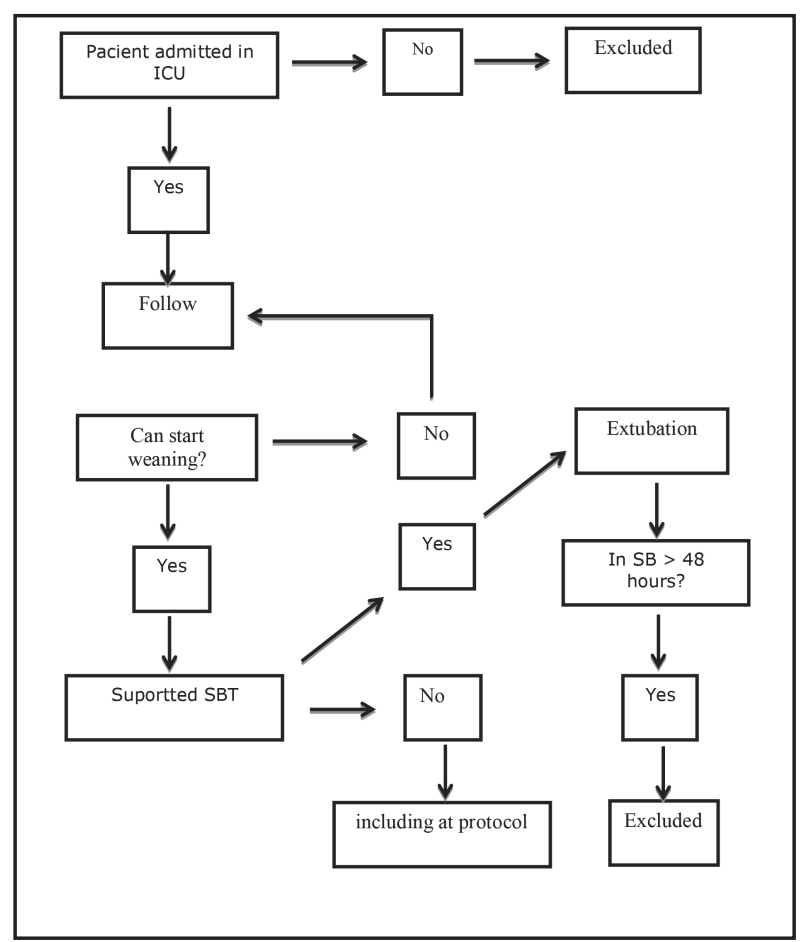

Figure 1. Study Design

Subtitle: MV (Mechanical Ventilation); SBT (Spontaneous Breathing Trial); SB (Spontaneous Breathing).
The comparison between the 76 (59.37\%) patients were extubated and the $52(40.62 \%)$ who died is shown in Table 3.

The patients who died eight arrived to conduct the SBT and presented RSBI average $123.20 \pm 57.57 \mathrm{bpm} / \mathrm{L}$, significant difference when compared to the extubated group averaging $68.76 \pm 46.21 \mathrm{bpm} / \mathrm{L}(\mathrm{p}=0.0038)$. It is emphasized that this variable was not used as a criterion for extubation in this study.

Thirteen patients $(10.16 \%)$ did not reach the criteria to be extubated and re-intubated and were thus included in weaning protocols. Thus two groups of similar characteristics received the treatment of T-tube (eight patients) or T-tube + Threshold $®$ IMT (five patients). No significant differences were found in variables between groups of different weaning protocols as shown in Table 4.

\section{DISCUSSION}

This study examined which variables determine the outcome of patients on MV, revealing that patients who died had lower levels of GCS and higher APACHE II, risk of mortality, length of MV and RSBI when compared to patients who were extubated. Those patients who failed in an attempt to extubation underwent two different methods of weaning, there was no significant difference in values for MIP, weaning time and duration of mechanical ventilation.

The GCS was originally designed to record and monitor the level of awareness of neurological patients, but now has also been used to predict the outcome of

Table 3. Variables in admitted patients in mechanical ventilation

\begin{tabular}{|c|c|c|}
\hline Variables & Group non-death & Group death \\
\hline n (\%) & $76(59.37)$ & $52(40.62)$ \\
\hline Age (years) $\S$ & $59.38 \pm 17.71$ & $61.04 \pm 18.19$ \\
\hline Mass $(\mathrm{kg}) \S$ & $57.39 \pm 8.46$ & $58.00 \pm 7.55$ \\
\hline Glasgow Coma Scale *\# & $8.00[3.00-11.00]$ & $3.00[3.00-3.00]$ \\
\hline Apache II*§ & $18.93 \pm 8.18$ & $26.59 \pm 6.22$ \\
\hline Risk of death $(\%)^{*} \#$ & $13.50[7.00-30.00]$ & $35.00[30.00-35.00]$ \\
\hline Days of MV (days)* $\S$ & $7.00 \pm 6.95$ & $8.72 \pm 6.31$ \\
\hline
\end{tabular}

Table 4. Comparison of the groups that performed the different protocols

\begin{tabular}{lcc}
\hline Variables & T-Tube & T-Tube+Threshold ${ }^{\circledR}$ IMT \\
\hline $\mathrm{N}$ & 8 & 5 \\
\hline Age (years) & $62.37 \pm 14.41$ & $65.40 \pm 10.88$ \\
\hline Initial MIP (mmHg) & $-32.25 \pm 17.87$ & $-33.20 \pm 9.34$ \\
Final MIP (mmHg) & $-34.25 \pm 16.68$ & $-28.00 \pm 10.95$ \\
\hline Length of weaning (days) & $4.87 \pm 1.96$ & $3.40 \pm 1.34$ \\
Days of MV (days) & $18.12 \pm 4.70$ & $17.80 \pm 6.83$ \\
\hline Values expressed in mean and standard deviaton; MIP= Maximum ventilatory pressure. mmHg: milimeters of mercury, MV: mechanical ventilation (p>0,05)
\end{tabular}


patients after trauma. ${ }^{(3,4)}$ It is known in elderly patients with brain injury and GCS less than 11 have a higher risk of death, persistent vegetative state or severe disability. (3) Patients with less than 9 more die than patients with GCS between 9 and 12, regardless of age initial GCS. ${ }^{(3)}$

The mean APACHE II of this study in the deceased group was 8 points above the extubation group, $40.62 \%$ of the patients died, this percentage was lower when compared with another study, which was $46.70 \%{ }^{(30)}$ patients lower values of APACHE II and younger are more likely to leave the hospital. $(1,2,6)$

MV patients die more when compared with patients breathing spontaneously, (30) and the risk increases when the MV time is longer than seven days. (32) The last statement was confirmed in our study, in which patients who died had an average MV 8.72 days compared with 7.00 days of which were extubated.

Values of RSBI lower than $105 \mathrm{bpm} / \mathrm{L}$ have high sensitivity to identify patients who will be successfully extubated. ${ }^{(14)}$ In this study, 11 of 76 extubated patients showed RSBI greater than 105bpm /L. The successful SBT can be useful to select patients for extubation. Patients who carry the SBT support for 30 to 120 minutes can be successfully extubated, (33) but some studies have shown that in $13 \%$ of cases may fail extubation of patients who completed this period, justifying the use of other associated parameters. ${ }^{34,35)}$

Regarding weaning protocols used in this study did not find significant differences between the groups, which agree with studies using respiratory muscle training with linear load or sensitivity adjustment, and have not been able to reduce the duration of MV. ${ }^{(25,26)}$ Patients undergoing respiratory muscle training showed decreased inspiratory muscle strength of approximately 5 $\mathrm{cmH} 2 \mathrm{O}$ and only patients who underwent T-tube showed increased strength in $2 \mathrm{cmH} 2 \mathrm{O}$, although the difference is not significant. As in the study by Caruso et al. (25) regardless of the group, the initial and final MIP were below normal, as was also observed in the present study.

The reasons for the failure to increase inspiratory muscle strength may be the low training load. In this study even with the fixed load by $50 \%$ if the patient had an increase in MIP training load would be higher, since to gain force is necessary to overload the enzymatic system, noting that critically ill patients have proteolysis, decreased muscle contractility and mitochondrial density. ${ }^{(36)}$

The study limitation was the small number of subjects to performe the weaning protocols, which can justify the no significant difference when comparing the two groups. In hospital clinical practice, before the study, weaning were made randomly, without the use of a protocol which could guide this process of mechanical ventilation weaning. This fact may have influenced that most patients were weaned successfully on the first try, and consequently generate a small number of patients included in the protocols for conducting this work. Another limitation was that there was not any control on the failure in the first weaning, nor the value of GCS on the spontaneous breathing trial.

It is still necessary to perform other randomized controlled studies with larger samples to further support the use of respiratory muscle strength training in the weaning process, since the benefits of this practice in other situations are already well understood.

\section{CONCLUSION}

The present study suggests that in patients who failed the spontaneous breathing trial variables that were important to the evolution of the patient regarding the outcomes studied were Glasgow Coma Scale, APACHE II, risk of mortality, duration of mechanical ventilation and rapid shallow breathing index. No differences in the variables studied when comparing two methods of weaning.

\section{REFERENCES}

1. Feijó CAR, Junior FOL, Martins ACS, Junior AHF, Cruz LLS, Meneses FA. Gravidade dos pacientes admitidos à Unidade de Terapia Intensiva de um hospital universitário brasileiro. Rev Bras Ter Intensiva. 2006; 18(1):18-21.

2. Cardoso LTQ, Matsuo T, Bonametti AM, Grion CMC. Avaliação do risco de mortalidade através do APACHE II para o CTI de um hospital escola público. Rev Bras Ter Intensiva. 2002; 14(3):85-94.

3. Ritchie PD, Cameron PA, Ugoni AM, Kaye AH. A study of the functional outcome and mortality in elderly patients with head injuries. J Clin Neurosci. 2000; 7(4):301-04.

4. Kuhls DA, Malone DL, McCarter RJ, Napolitano LM. Predictors of mortality in adult trauma patients: the physiologic trauma score is equivalent to the trauma and injury severity score. J Am Coll Surg. 2002; 194(6): 694-704.

5. Knaus WA, Draper EA, Wagner DP, Zimmerman JE. APACHE II: a severity of disease classification system. Crit Care Med.1985; 13(10):818-29.

6. Esteban A, Alía I, Ibañez J, Benito S, Tobin MJ. Modes of mechanical ventilation and weaning. A national survey of Spanish hospitals. Chest. 1994a; 106(4):1188-93. 
7. Goldwasser R, Farias A, Freitas EE, Saddy F, Amado V, Okamoto VN, et al. Desmame e interrupção da ventilação mecânica. Rev Bras Ter Intensiva. 2007; 19(3):384-92.

8. Colombo T, Boldrini AF, Juliano SRR, Juliano MCR, Houly JGS, Gebara OCE, et al. Implementação, avaliação e comparação dos protocolos de desmame com Tubo-T e Pressão Suporte associada à pressão expiratória final positiva em pacientes submetidos à ventilação mecânica por mais de 48 horas em unidade de terapia intensiva. Rev Bras Ter Intensiva. 2007; 19(1):31-7.

9. Jerre G, Beraldo MA, Silva TJ, Gastaldi A, Kondo C, Leme F, et al. Fisioterapia no paciente sob ventilação mecânica. Rev Bras Ter Intensiva. 2007; 19(3):399-407.

10. MacIntyre NR, Cook DJ, Ely EW, Epstein SK, Fink JB, Heffner JE, et al. Evidence - based guidelines for weaning and discontinuing ventilatory support. Chest. 2001;120(6):375S-95S.

11. Assunção MSC, Machado FR, Rosseti HB, Penna HG, Serrão CCA, Silva WG, et al. Avaliação de teste de tubo T como estratégia inicial de suspensão da ventilação mecânica. Rev Bras Ter Intensiva. 2006; 18 (2):121-25.

12. Esteban A, Alía I, Gordo F, Fernandez R, Solsona JF, Vallverdú I, et al. Extubation outcome after spontaneous breathing trials with T-tube or pressure support ventilation. Am J Respir Crit Care Med. 1997; 156(2):459-65.

13. Esteban A, FrutoS F, Tobin MJ, Alía a, Solsona JF, Valverdú I, et al. A comparison of four methods of weaning patients from mechanical ventilation. N Engl J Med. 1995; 332(6):345-50.

14. Yang $\mathrm{KL}$, Tobin MJ. A prospective study of indexes predicting the outcome of trials of weaning from mechanical ventilation. N Engl J Med. 1991; 324(21):1445-50.

15. Krieger BP, Isber J, Breitenbucher A, Throop G, Ershowsky P. Serial measurements of the rapid-shallow-breathing index as a predictor of weaning outcome in elderly medical patients. Chest. 1997; 112(4):1029-34.

16. França EET, Ferrari F, Fernandes P, Cavalcanti R, Duarte A, Martinez BP, et al. Fisioterapia em pacientes críticos adultos: recomendações do Departamento de fisioterapia da Associação de Medicina Intensiva Brasileira. Rev Bras Ter Intensiva. 2012; 24(1): 6-22.

17. Vassilakopoulos T, Petrof BJ. Ventilator-induced diaphragmatic dysfunction. Am J Respir Crit Care Med. 2004; 169(3):336-41.

18. Capdevila X, Lopez S, Bernard N, Rabischong E, Ramonatxo M, Martinazzo G, et al. Effects of controlled mechanical ventilation on respiratory muscle contractile properties in rabbits. Intensive Care Med. 2003; 29(1):103-10.

19. Mambro TRD, Figueiredo PHS, Wanderley TR, Kristki AL, Guimarães FS. Treinamento muscular inspiratório na doença pulmonar obstrutiva crônica: impacto na qualidade de vida, intolerância ao esforço e dispnéia. Fisioter Pesqui. 2007; 14(2): 65-71.

20. Riera HS, Rubio TM, Ruiz FO, Ramos PC, Otero DDC, Hernandez TE, et al. Inspiratory muscle training in patients with COPD: effect on dyspnea, exercise performance, and quality of life. Chest. 2001; 120(3):748-56.

21. Ysayama L, Lopes LR, Silva AMO, Andreollo NA. A influência do treinamento muscular respiratório pré-operatório na recuperação de pacientes submetidos à esofagectomia. ABCD. Arq Bras Cir Dig. 2008; 21(2):61-4.

22. Martin AD, Davenport PD, Franceschi AC, Harman E. Use of inspiratory muscle strength training to facilitate ventilator weaning: a series of 10 consecutive patients. Chest. 2002;122(1):192-6.

23. Santos AR, Fogliatto CS, Soares J, Gonçalves M. Aplicação de treinamentos muscular ventilatório específico durante o processo de desmame da ventilação mecânica - relato de caso. Discip Sci. 2001; 2(1):33-40.

24. Sprague SS, Hopkins PD. Use of inspiratory strength training to wean six patients who were ventilator-dependent. Phys Ther. 2003; 83(2):171-81.

25. Caruso P, Denari SDC, Ruiz SAL, Bernal KG, Manfrin GM, Friedrich C, et al. Inspiratory muscle training is ineffective in mechanically ventilated critically ill patients. Clinics. 2005; 60(6):479-84.

26. Condessa RL. Avaliação do Treino muscular inspiratório por threshold IMT no processo de aceleração do desmame da ventilação mecânica [dissertação]. Porto Alegre: Universidade Federal do Rio Grande do Sul; 2008.

27. Gabbe BJ, Cameron PA, Finch CF. The status of the Glasgow Coma Scale. Emerg Med. 2003; 15:353-60.

28. Rufino R, Costa CH, Antao VCS, Pinheiro GA, Jansen JM. Relação envergadura/altura: um valor para estudos espirométricos em brasileiros. Pulmao/RJ. 1996; 7:40-4.

29. Marini JJ, Smith TC, Lamb V. Estimation of inspiratory muscle strength in mechanically ventilated patients: measurement of maximal inspiratory pressure. J Crit Care. 1986; 1(1):32-8.

30. Colpan A, Akinci E, Erbay A, Balaban N, Bodur H. Evaluation of risk factors for mortality in intensive care units: $A$ prospective study from a referral hospital in Turkey. Am J Infect Control. 2005; 33(1):42-7.

31. Gonçalves WM, Kruel NF, Araújo PA, Teixeira DO. Análise do sistema prognóstico de mortalidade APACHE II em pacientes cirúrgicos de unidade de terapia intensiva. Rev Col Bras Cir. 1999; 26(2):115-8.

32. Oliveira ABF, Dias OM, Mello MM, Araújo S, Dragosavac D, Nucci A, Falcão ALE. Fatores associados à maior mortalidade e tempo de internação prolongado em uma unidade de terapia intensiva de adultos. Rev Bras Ter Intensiva. $2010 ; 22(3): 250-6$. 
33. Esteban A, Alía I, Tobin MJ, Gil A, Gordo F, Vallverdú I, et al. Effect of spontaneous breathing trial duration on outcome of attempts to discontinue mechanical ventilation. Am J Respir Crit Care Med. 1999; 159:512-8.

34. Nemer SN, Barbas CSV. Parâmetros preditivos para o desmame da ventilação mecânica. J Bras Pneumol. 2011; 37(5):669-79.

35. Vivar FF, Ferguson ND, Esteban A, Epstein SK, Arabi Y, Apezteguia C, et al. Risk factors for extubation failure in patients following a successful spontaneous breathing trial. Chest. 2006; 130(6):1664-71.

36. Wagenmakers AJM. Muscle function in critically ill patients. Clin Nutr. $2000 ; 20(5): 451-4$ 